\title{
From This Day Forward: A Feminine Moral Discourse on Homosexual Marriage
}

\author{
Claudia A. Lewis
}

The definitional equation of marriage with heterosexuality forms a selfenclosed system inaccessible to single-gender couples who desire equal protection under the law for their intimate enduring relationships. The summary state denial of homosexual marriage ${ }^{2}$ exposes the fundamental right to marry, deemed to inhere in the individual, ${ }^{3}$ as an exclusive privilege conditioned upon heterosexual orientation.

During the past decade, commentators have argued that the proscription of homosexual marriage violates the constitutional mandate of equal protection under the Fourteenth Amendment.* They have unwittingly assumed, however, that the Court would take such challenges seriously, and that conventional equal protection analysis provides a principled and coherent means to eliminate the selective application of the right to marry. After Bowers v. Hardwick, wherein the Court ridiculed homosexuals' claim to privacy for their intimate sexual relations as "at best, facetious," homosexuals' claim to marry may readily be dismissed by the Court as "at best, absurd."

This Note examines the homosexual marriage challenge anew to investigate, through the lens of feminist jurisprudence, ${ }^{\beta}$ why the courts have

1. There is a danger in labeling the discourse in this Note "feminine" as it threatens to exclude and may fail to engage male readers. Such separation may lead to its devaluation. But to name, at times, is to empower. Lecture by Professor Toril Moi at Yale Graduate School (December, 1987). My purpose in employing feminist theory is to demonstrate that its lens of questioning, rethinking, and redefining terms promises valuable insights into the law in a voice new to, but compatible with, the Iegal domain.

2. See Singer v. Hara, 11 Wash. App. 247, 522 P.2d 1187 (1974) (homosexual marriage prohibition upheld); Jones v. Hallahan, 501 S.W.2d 588 (Ky. 1973) (same); Baker v. Nelson, 291 Minn. 310, 191 N.W.2d 185 (1971) (same), appeal dismissed, 409 U.S. 810 (1972). Most state statutes do not expressly prohibit single-gender marriage. But see TEx. FAM. CoDE ANN. $\$ 1.01$ (Vernon 1975) ("A license may not be issued for the marriage of persons of the same sex.")

3. See Loving v. Virginia, 388 U.S. 1, 12 (1967) ("the freedom to marry . . . resides with the individual").

4. See, e.g., Ingram, A Constitutional Critique of Restrictions on the Right to Marry - Why Can't Fred Marry George - or Mary and Alice at the Same Time?, 10 J. CoNTEMP. L. 33 (1984); Note, The Legality of Homosexual Marriage, 82 YALE L.J. 573 (1973). But see Buchanan, Same-Sex Marriage: The Linchpin Issue, 10 U. DAYTON L. Rev. 541 (1985).

5. 478 U.S. 186, 194 (1986).

6. Rather than setting a particular political agenda, as a jurisprudential method, feminism is pri- 
refused and will continue to refuse to recognize homosexuals' fundamental right to marry. Feminist legal scholars have shown the inadequacy of traditional equal protection analysis to overcome the pervasive gender inequality that impedes women's full integration into the workplace. ${ }^{7}$ Equal protection theory and doctrine also fail to respond to the forced invisibility of homosexual relationships. "Strict scrutiny" of the single-gender marriage claim reveals that conventional analysis suffers from an impoverished conceptual framework of equality, most notable for what it ignores: human interconnection and care.

The inclusion of the "ethic of care," associated with the feminine moral voice, and a more serious concern for the existing "ethic of justice" in equality discourse promises a richer vision of equality grounded in respect for the multiplicity of human differences and moral responsibilities to others. ${ }^{9}$ Empathy provides a new tool to expand the dialogue and enrich the moral imagination. Under such an expanded moral framework, the substantive right to equality moves beyond the anti-discrimination principle and approaches an affirmative right to connection to and response from the community. Homosexuals' right to marry originates from this broader right of attachment, for the most intimate human connections form the building blocks to a cohesive community.

marily a process of consciousness raising, of questioning the law and the view of human nature underlying it. Feminist scholars critique and strive to resist the abstraction and professed objectivity of legal doctrine and rules in seeking solutions to inequality. See Scales, The Emergence of Feminist Jurisprudence: An Essay, 95 YALE L.J. 1373, 1374-75 (1986). They self-consciously avoid translating problems of social inequity into legal language, see Wildman, The Legitimation of Sex Discrimination: A Critical Response to Supreme Court Jurisprudence, 63 OR. L. REv. 265, 286-87 (1984), turning instead to psychological and philosophical theories on relationalism in social thought as tools to create an enlarged legal dialogue intended to respond more persuasively to the human predicament. Because feminists tend to avoid the universal, feminist theory is offered as one of many lenses through which to percieve truth and yield partial and contingent explanations. Lecture by Professor Clare Dalton at Yale Law School (November, 1987) (on post-modern feminism). This Note is not based on a single feminist theory, or solely on feminist theory, as no single theory should attempt to speak for all feminists. The feminist method is destructive only when it is insistent and inflexible. Id. See Minow, The Supreme Court, 1986 Term - Foreword: Justice Engendered, 101 Harv. L. Rev. 10, 62-66 (1987) [hereinafter Justice Engendered]. (Professor Minow has adopted a "social relations" approach to equality jurisprudence, informed and inspired by feminist theory though not avowedly "feminist.")

7. See, e.g., C. Mackinnon, Sexual Harrassment of Working Women (1979); Finley, Transcending Equality Theory: $A$ Way Out of the Maternity and the Workplace Debate, 86 Colum. L. REv. 1118 (1986); Scales, supra note 6.

8. This Note exposes the failure of our legal system to address not only overt discrimination against homosexuals, but also homosexuals' basic needs with regard to the family. Cf. Finley, supra note 7 , at 1143 , n.110 (pregnancy discrimination reflects similar failure with regard to women's needs). The "feminist" method applies not only to women's issues, but to all human issues.

9. See C. Gilligan, In a Different Voice: Psychological Theory and Women's DevelOPMENT (1982). The "ethic of care" and "ethic of justice" respectively refer to girls' and boys" typical modes of solving moral dilemmas. The ethic of care, or responsibility, "relies on the concept of equity, the recognition of differences in need," while the ethic of justice, or rights, is "a manifestation of equal respect, balancing the claims of other and self." Id. at 164-65. See infra text accompanying notes 34-41. 


\section{The Failure of Traditional Equal Protection Analysis}

\section{A. The Impoverished Equal Protection Ideal}

The ideal of equality underlying traditional equal protection analysis demands only that persons who are alike must be treated alike. ${ }^{10}$ The proclamation of difference, therefore, legitimizes existing inequity. ${ }^{11}$ Under the "similarly situated" ideal, biological and deep psycho-social differences pose a formidable barrier to equal treatment. To prove their suitability to marry, homosexual couples will either have to deny the importance of the sexual aspect of marriage or diminish the significance of their sexual orientation. Because the former is unthinkable, homosexual couples will have to deny their difference to achieve equality. From the feminist perspective, it is discriminatory to force homosexuals, as a precondition to their access to fundamental rights, to declare the irrelevance of an essential aspect of their humanity. ${ }^{12}$

The "similarly situated" ideal equating equality with sameness and difference with inferiority is flawed not only because it devalues human individuality but also because it offers no guidelines for determining when two persons are alike or not for the purposes of the Fourteenth Amendment. ${ }^{13}$ It "reposes confidence in the perceptions of the judiciary about similarities that transcend as well as differences that endure."14 The judiciary would have us believe that this ideal offers an objective and value-neutral approach to inequality. It does not. A prejudice towards difference, towards those unlike the norm, is built into equality jurisprudence.

10. See e.g., F.S. Royster Guano Co. v. Virginia, 253 U.S. 412, 415 (1920) ("all persons similarly circumstanced shall be treated alike").

11. Dalton, supra note 6 (where law sees difference, it justifies disadvantages).

12. Lesbian mothers in custody disputes have found that they are forced to deny pride in their lesbian sexuality and to appear part of the mainstream. They must enter the courtroom armed with empirical evidence that heterosexual and lesbian mothers have similar sex-role behavior and attitudes towards child-rearing. "[W]hen we constantly assert in the public arena that we will raise our children to be heterosexual, and that we will protect them from manifestations of our sexuality and from the larger lesbian and gay community, we lose something that affects all lesbian and gay men. We essentially concede that it is preferable to be heterosexual, thereby foreclosing an assertion of pride and of the positive value in homosexuality." Polikoff, Lesbian Mothers, Lesbian Families: Legal $O b$ stacles, Legal Challenges, 14 N.Y.U. Rev. L. \& Soc. ChaNge 907, 908-09 (1986).

13. See Minow, When Difference Has Its Home: Group Homes for the Mentally Retarded, Equal Protection and Legal Treatment of Difference, 22 HARv. C.R.-C.L. L. REv. 111, 127 (1987) [hereinafter Difference] ("Some governmental actions imposing differential treatment on the basis of group differences will survive the searching inquiry of rights analysis; yet, rights analysis itself does not explain why.").

14. Id. at 124. Professor Minow asserts that rights analysis is only dubious of classification when there has been a history of prejudice; the class is hence inherently "suspect." Id. Traditional equal protection has proved successful for blacks and others deemed members of a suspect class; their difference then becomes an "irrelevant accident" to which "Justice must be blind." Tussman \& tenBroek, The Equal Protection of the Laws, 37 CALIF. L. Rev. 341, 353 (1949). Homosexuals have fared less well, in part because there is scant evidence of their history of overt discrimination and political underrepresentation. "A minority must exist before it can be oppressed, but a socially-defined, selfconscious homosexual minority simply does not exist very far back in the nations's past." D'Emilio, Making and Unmaking Minorities: The Tensions Between Gay Politics and History, 14 N.Y.U REv. L. \& Soc. Change 915, 920 (1986). 
Difference is intelligible only as a statement of relationship; rather than intrinsic, difference is a social construct designed to confirm superiority. ${ }^{15}$ Judges, therefore, both create and defeat equality from a relation of power to the differences they construct. ${ }^{16}$ When those possessing the power to set the norm are heterosexual, they easily classify homosexuals as the deviant "other" to justify the unequal burdens homosexuals bear, including their confinement "to the closet." Because judges embed their unstated white, heterosexual male point of comparison in categories and labels, differences appear neutral, inevitable and true. To percieve an "other" is an ontological weapon, ${ }^{17}$ however, wielded by those with the power to claim the "true" perspective and ignore the multiplicity of "other" perspectives. Ultimately, this weapon disembodies the "other" and renders her suffering invisible.

\section{B. The Snare of Rule-Bound Doctrine}

To determine whether state statutes defining marriage as "a union of man and woman" violate the equal protection clause of the Fourteenth Amendment, a court will initially become mired in confusion over which "tier of scrutiny" should apply. It must determine whether the class excluded from the right is suspect or non-suspect, ${ }^{18}$ and whether the right at issue is fundamental or not, ${ }^{19}$ in order to decide whether to examine the

15. Minow, Difference, supra note 13, at 128-29; Minow, Justice Engendered, supra note 6, at 35-36. The disjunction between self and "other" contains the seeds of domination, see Scales, supra note 6 , at 1382 , - of male over female, straight over gay, public over private, and market over family.

16. Minow, Justice Engendered, supra note 6, at 13-15. Feminist scholars have come to discover that when men postulate "a self-referential standard as the objectively inclusive norm," women are hard-pressed in their fight for equality. Finley, supra note 7, at 1152-59. See Scales, supra note 6, at 1377-78. The association of the masculine perception with the rational self has led to the hierarchical interpretation of masculine principles as superior to the inferior principles of the feminine "other." See Whitbeck, A Different Reality: Feminist Ontology, in Beyond Domination: New Perspectives on Women AND Philosophy 67 (C. Gould ed. 1983).

17. Moi, supra note 1 .

18. With the exception of the short-lived ruling in Watkins v. United States Army, 837 F.2d 1428 (9th Cir. 1987), nullified on June 8, 1988 and expected to be reversed en banc in early 1989, homosexuals have not been regarded as an inherently suspect class, particularly in the wake of Hardwick. See Padula v. Webster, 822 F.2d 97, 103 (D.C. Cir. 1987) ("It would be quite anomolous, on its face, to declare status defined by conduct that states may constitutionally criminalize as deserving of strict scrutiny under the equal protection clause."). Thus unless a court takes into consideration the creative arguments in Watkins, it need not deliberate at length on this prong of the test.

19. The question whether marriage is a fundamental right triggering strict scrutiny may generate dispute. In Loving $v$. Virginia, although the Court could have declared Virginia's miscegenation statute prohibiting interracial marriage unconstitutional solely on the basis of an invidious racial classification violative of the equal protection clause, it recognized the "freedom of choice to marry" as a fundamental liberty under the due process clause of the Fourteenth Amendment because it is "one of the vital personal rights essential to the orderly pursuit of happiness by free men." Loving, 388 U.S. 1,12 .

In Zablocki v. Redhail, the Court confirmed the right to marry as one of "fundamental importance for all individuals." 434 U.S. 374, 384 (1978). In the equal protection analysis that ensued, Justice Marshall invoked his unique "sliding scale" formulation of equal protection: "When a statutory classification significantly interferes with the exercise of a fundamental right, it cannot be upheld unless it is supported by sufficiently important state interests and is closely tailored to effectuate only those interests." Id. at 388. There was division in Zablocki as to whether this approximation of strict scru- 
legislation in question with "strict," "heightened," or "minimum" scrutiny. ${ }^{20}$

Under the minimal scrutiny of rational relations test, courts in previous homosexual marriage challenges have taken a traditional deferential stance and accepted the state's construction of marriage as having the dual purposes of fostering procreation and traditional morality, thereby defeating the single-gender marriage challenge. ${ }^{21}$

Requiring that exclusionary classifications merely be "rationally related" to a state interest largely results in an abdication of judicial review. ${ }^{22}$ A court may avoid explanation and circumvent responsibility by deferring to a government's avowed purpose. ${ }^{23}$ There need be no searching examination of the legitimacy of the state's purpose in maintaining marriage as a heterosexual privilege or of majoritarian moral sentiments regarding homosexuality. ${ }^{24}$ Nor need the court articulate with any precision the moral objectives the marriage classification serves.

Though the tiered analysis is intended to be a procedural approxima-

tiny should be followed. The Justices differed widely as to the proper intensity of review in accordance with their evaluation of the fundamental nature of the right at stake. The hesitation to apply strict scrutiny may have been due to the fact that it has been "strict' in theory . . . [but] fatal in fact." Gunther, The Supreme Court, 1971 Term-Foreword: In Search of Evolving Doctrine on a Changing Court: A Model for a Newer Equal Protection, 86 HARv. L. REv. 1, 8 (1972). Such strict scrutiny might essentially put marriage beyond the government's reach and erase a history of state control. See Pennoyer v. Neff, 95 U.S. 714, 734-35 (1877).

Animosity towards homosexual relationships may lead a court to deny the fundamental nature of the right to marry as applied to lesbian and gay couples. It may interpret narrowly the marital right according to its tradition as the monogamous union of a man and woman for the purposes of procreation and child-rearing, feeling less inclined to take an expansive approach to it because the fundamental right to marry has no direct textual support in the Constitution. See Hardwick, 478 U.S. at 194 ("The Court is most vulnerable and comes nearest to illegitimacy when it deals with judge-made constitutional law having little or no cognizable roots in the language or design of the Constitution.").

20. The level of review determines how narrow the "fit" must be between legislative ends and means; that is, whether the state interests advanced in support of the exclusionary classification must be "compelling," "sufficiently important," or merely "rational". See generally Tussman \& tenBroek, supra note 14 .

21. Baker v. Nelson, 291 Minn. 310, 191 N.W.2d 185 (1971), and Singer v. Hara, 11 Wash. App. 247, 522 P.2d 1187 (1974), upheld state marriage statutes excluding homosexuals under rational relations tests, relying on the inextricable link between marriage and procreation to justify differential treatment of homosexual couples whose union poses the "impossibility of reproduction." Singer, 522 P.2d at 1195. The Baker court acknowledged that the state does not impose on heterosexual couples the condition that they are willing and able to procreate, but it dismissed this argument by asserting that "the classification is no more than theoretically imperfect." Baker, 191 N.W.2d at 187 (citation omitted). This Note assumes that courts will also dismiss the argument that artificial technology and surrogate motherhood now enable single-gender couples to procreate-that is, that courts will still be wed to traditional notions of procreation.

22. See, e.g., Gunther, supra note 19, at 8.

23. See Minow, Justice Engendered, supra note 6, at 83-86 (deference and reliance on doctrinal boundaries may preempt questions or exempt reason-giving).

24. Because sexual orientation has not been considered a suspect classification, the government has not been forced to elucidate its morality interest underlying legislation discriminating against homosexuals. See Note, The Constitutional Status of Sexual Orientation: Homosexuality as a Suspect Classification, 98 HARv. L. REv. 1285, 1305 (1985). Subjecting Georgia's sodomy statute to the test of rationality, the Court in Hardwick, with no discussion or explanation, asserted that it simply did not agree that "majority sentiments about the morality of homosexuality should be declared inadequate." 478 U.S. at 196. 
tion of equal protection of the laws, the formalism of the process obscures the right shaping its contours. ${ }^{25}$ The term "equality" is noticeably absent from these multi-leveled tests. If justification of exclusion is to be taken seriously, however, primary allegiance should be to the constitutional mandate of equality, not to an incoherent and "rudderless" procedure. ${ }^{28}$

By translating the equal protection ideal into a proliferation of rules and classifications, the judiciary has created a guise for its power, enabling it to avoid responsibility for perpetuating the inequities experienced by the "other." The language of equal protection is its instrument of deception. ${ }^{27}$ Just as the reliance on "controlling" precedent implies that the legal process yields results of its own accord, ${ }^{28}$ the language of tests and fidelity to rules allow the decisionmaker to avoid the moral dimensions and painful consequences of decisions. ${ }^{28}$ Rational rules with universal application promise certainty and suppress emotion. The labels and categories used to classify individuals are "masks" behind which humanity is hidden and disavowed. ${ }^{30}$ When those masks obfuscate the substantive right to equality, the judiciary fails to live up to its role. ${ }^{31}$ Though the rules may be abstract, the victims of power are not. Masks embodying the power to proclaim difference foster inhuman neglect and merciless conformity.

\section{Empathy-A Tool To Stretch The Moral Imagination}

Justice, if "blind," provides the illusion of simplicity, certainty and omnipotent truth-and obscures the pain engendered by not seeing. The failure of equal protection may rest, in part, on the myopia of the masculine moral vision hindering our commitment to equality. The feminist quest is to restore judicial vision and compel the courts to respond meaningfully to inequality. The tool to open the eyes of the judiciary is empathy, a femi-

25. See Scales, supra note 6, at 1385 ("[Feminism] is vitally concerned with the oblivion fostered by lawyers' belief that process is what matters.").

26. See Karst, The Supreme Court, 1976 Term -Foreword: Equal Citizenship Under the Fourteenth Amendment, 91 HARv. L. REV. 1, 3 (1977) ("Surely we are near the point of maximum incoherence of equal protection doctrine."); Massachusetts Bd. of Retirement v. Murgia, 427 U.S. 307, 321 (1976) (Marshall, J., dissenting) (finding the Court's approach to equal protection "rudderless, ... giving no firm guidance to judges").

27. Cf. Stark, Why Lawyers Can't Write, 97 HaRv. L. Rev. 1389, 1390 (1984) ("Language . . . limits what lawyers can see.").

28. See Minow, Justice Engendered, supra note 6, at 35, 85 (noting that focus on precedent leads a court repeatedly to assign sameness and difference, yet it pretends that such an assignment is beyond its control); Stark, supra note 27, at 1391.

29. See Henderson, Legality and Empathy, 85 MiCH. L. Rev. 1574, 1590 (1987). But see Watkins v. United States Army, 837 F.2d 1428, 1452 (9th Cir. 1987) (Reinhardt, J., dissenting) ("[Bound by precedent], I am sometimes compelled to reach a result I believe to be contrary to the proper interpretation of constitutional principles. This is regrettably one of those times.").

30. J. Noonan, Persons and Masks of the Law 19-20 (1976).

31. "[T]he judge who has forgotten the purpose of justice is almost surely masked." Id. at 21. Line-drawing and categorizing too often "closes our eyes to basic reasons for constitutional shelter." Hardwick, 478 U.S. at 203 (Blackmun, J., dissenting). 
nine lens absent from the rights-based legal domain. By connecting imaginitively with the human dimension of social inequities, the judiciary may bring law back from the plane of abstraction to its purpose: resolving moral dilemmas-on human, not just legal terms. ${ }^{32}$ In the process, they may discover that the notion of equality is in need of expansion. ${ }^{33}$

\section{A. Two Moral Voices-Two Moral Visions}

Justice without question has a moral dimension. The studies of developmental psychologist Carol Gilligan on gender difference in moral development have thus inspired feminist legal scholars to ponder the consequences of the exclusion of women's point of view from the creation of law and the administration of justice. ${ }^{34}$ Many conclude that the existing male-dominated jurisprudence distorts the fundamental tension between autonomy and connection, individual and community, and rules and equity, privileging the former over the latter. ${ }^{35}$ The recognition that there are two contexts for moral decision-justice and care-makes judgment by definition contextually relative and may lead the judiciary to a new understanding of responsibility and choice. ${ }^{36}$

In her studies, Professor Gilligan observed that girls and boys use two different ethics to solve moral dilemmas. ${ }^{37}$ These two orientations generate distinct but related moral injunctions-not to treat others unfairly, and

32. See Dubois, Dunlap, Gilligan, MacKinnon \& Menkel-Meadow, Feminist Discourse, Moral Values and the Law-A Conversation, 34 Buffalo L. REv. 11, 51 (1985) [hereinafter Conversation]; Scales, supra note 6, at 1387.

33. Listening to neglected human voices may demonstrate that a legal principle or decision is deficient and needs to be changed to "comport with a just ordering of human voices." Yudof, "Tea at the Palaz of Hoon": The Human Voice in Legal Rules. 66 TEx. L. REv. 589, 611 (1988).

34. See, e.g., Finley, supra, note 7; Menkel-Meadow, Toward Another View of Legal Negotiation: The Structure of Problem Solving, 31 UCLA L. Rev. 754 (1984); Scales, supra note 6; Sherry, Civic Virtue and the Feminine Voice in Constitutional Adjudication, 72 VA. L. REv. 543 (1986).

35. See, e.g., Finley, supra note 7, at 1177; Sherry, supra note 34, at 580-82.

36. See C. Gilligan, supra note 9, at 166.

37. Each ethic originates in the young child's awareness of his self in relation to others. See Gilligan \& Wiggins, The Origins of Morality in Early Childhood Relationships 4 (November, 1985) (unpublished manuscript available in Yale Law School Library). Because masculinity is defined through separation and individuation, boys tend to view the autonomy of individuals as the paramount value of our moral universe. They perceive moral problems as the result of conflicting and competing rights, belonging to the self and to the "other," which require hierarchical "rules" for their resolution. The rules formulating an "ethic of justice" or "ethic of rights" allow for a winner and a loser in a logical although abstract fashion, transcending the immediacy of the conflict at hand. See N. Chodorow, The Reproduction of Mothering: Psychoanalysis and the Psychology of GENDER 166-68 (1978); C. Gilligan, supra note 9, at 25-51.

Femininity, on the other hand, is defined through identification and attachment. Because female ontology does not define by negation, "relationships between people are understood as developing through identification and differentiation, through listening and speaking, with each other, rather than through struggles to dominate or annihilate the other." Whitbeck, supra note 16 , at 76 . See N. Chodorow, supra, at 166-68. The experience of attachment underlies the conception of morality as love, the need to respond to another. Gilligan \& Wiggins, supra, at 5. Girls' understanding of morality arises from the recognition of relationships, the belief in communication as the best way to resolve conflict, and the conviction that compelling representation of dilemmas will bring about resolution. $C$. Gilligan, supra, at 30. Guided by an "ethic of responsibility" or "ethic of care," girls tend to devalue rules that interfere with the preservation of relationships. Id. at 10, 44 . 
not to turn away from others in need. Though their resulting decisions may converge, the two methodologies are in fundamental tension with one another. From the justice perspective, detachment is necessary to define transcendent rights. In the framework of care, such lack of connection is perceived as a grave moral danger. ${ }^{38}$ Ultimately, the integrity of each mode requires their interconnection, for "[a]bandonment of the rules produces monsters; so does neglect of persons." "s9

Most people, male and female, speak in both the voice of justice and the voice of care when describing moral conflict. ${ }^{40}$ Out of the desire to reduce ambiguity and arrive at certainty, however, a majority of people focus on one language or the other, typically according to their gender. ${ }^{11}$ The masculine voice of rights has dominated legal discourse.

Through the feminine moral lens, traditional equal protection analysis is morally "underinclusive." The more controversy generated over the tier of scrutiny and the nature of the right, the further a court is removed from context and connection, from the integration of justice and care. To avoid social change and perpetuate the status quo subjecting homosexual relationships to segregation and hiding, a court need only proclaim to the single-gender couple seeking equal protection for their fundamental right to marry, "You are different." Its voice, however, will be muffled in obfuscation, necessary to shield the pain of abandoning the "other."

\section{B. The Myopic Judicial Vision of Homosexual Relationships}

The Supreme Court grievously illustrated the oppressive consequences of the myopic masculine discourse in Hardwick. The Court's assumption of the opposition of homosexuality and the family"2 promoted a "willful blindness:" 43 the failure to question the validity of the assumption and its consequences. Though the lack of connection at first blush appears "natural," for by their sexual union homosexuals cannot procreate, the Court failed to acknowledge that only state prohibitions-legal constructs-bar homosexuals from marrying and raising families. ${ }^{44}$ Such blindness rein-

38. See Gilligan \& Wiggins, supra note 37 , at 14.

39. J. Noonan, supra note 30 , at 18.

40. See Gilligan \& Wiggins, supra note 37 , at 39.

41. See id. at 10-11.

42. The Court denied homosexuals' right to engage in private consensual sexual conduct largely because of the majority's misguided belief that there is "[n]o connection between family, marriage or procreation on the one hand and homosexual activity on the other . . ." Hardwick, 478 U.S. at 191 (distinguishing other cases upholding an individual's right to privacy).

43. Id. at 205 (Blackmun, J., dissenting) (referring to majority's failure to recognize sexual intimacy as central relationship of human existence).

44. When socially or legally constructed differences are viewed as natural, and hence legitimate, they are all too often immunized from searching examination by the Court. See Kronman, Alexander Bickel's Philosophy of Jurisprudence, 94 YALE L.J. 1567, 1603 (1985) ("The temptation to place the moral foundations of society in a pre-existing state of nature reflects the powerful wish to give one's favored scheme of values a precision and unconditional legitimacy that put it safely beyond the realm of political controversy."); Minow, Difference, supra note 13, at 173 ("we use stereotypes to structure 
forces the "naturalness" of the stereotype of homosexuality as antithetical to family values. ${ }^{45}$

If the Court's starting point for analysis had been the recognition of the interrelation between sexual intimacy, love, relationships and the family, rather than a blind stereotype, perhaps the majority would not have dismissed the claim to privacy so blithely or left unexamined the presumed immorality of homosexual activity. Reality belies the myth of homosexuals as aberrant loners who bear no relation to the tenderness associated with marriage and the family. Only a pathological twist of the social memory forgets that homosexuals are born into and raised by families. If the Court would only recognize this-if it would make the connection-perhaps it would better understand that, like heterosexuals, homosexuals desire the warmth and security of intimate relationships created by marriage and the family. The human proclivity for forming traditional family bonds is deeply socially ingrained and not dependent on sexual orientation.

Why is it that a majority of the Court failed to see beyond the stereotypes that prevent homosexuals from gaining access to their basic civil rights? The Justices probably viewed sodomy between same gender couples with such distaste, if not revulsion, that they failed to see that from the viewpoint of homosexual couples, at least those who desire to pledge themselves to one another in marriage, these sexual acts may be the most "natural" expressive acts of love and care. Only in the eyes of the heterosexual beholder, who possesses the power to attribute difference, is sodomy performed by members of the same sex "unnatural." This distorted vision of Hardwick is, in part, endemic to constitutional jurisprudence. Because the Court need never "connect" with the party seeking redress on appeal, but need only think in terms of the anonymous "individual" in a rule-bound game, it may avoid emotional reciprocity and "the moral crux of the matter in real human situations." stereotype reflects, above all, the failure of empathic imagination-the failure to imagine the perspective of the "other."

the world, localize anxieties and lend appearances of legitimacy and self-evident truth to what we have invented").

45. The view of homosexuality as the negation of the family has led courts to perceive the very concept of "homosexual parents" as an oxymoron. See, e.g., In Re Davis, 1 Fam. L. Rep. (BNA) 2845, 2846 (Wash. Super. Ct. 1975) ("Substituting two male homosexuals for 'parents' does violence not only to the literal definition of who are parents but offends the traditional concept of what a family is."); see also B. MADDOX, MARRIED AND GAY (1982) (discussing societal prejudice against homosexual parenthood).

46. Scales, supra note 6, at 1387 ; see Henderson, supra note 29, at 1639 ("Mr. Hardwick never appeared in the briefs or arguments as a human being. . . . He became another disembodied person onto whom fears, prejudices, and false beliefs could be projected."). 


\section{The Promise of Imagination: Revealing the Invisible}

Objectivity need not spell insensitivity. It may be redefined to require only disengagement from the immediacy of personal desire and values, rather than the negation of care altogether. ${ }^{47}$ Judgment requires the free exercise of the moral imagination to enable the adjudicator to identify with the party before him and suspend his own cultural beliefs. ${ }^{48}$ If the judiciary is to meet its responsiblity as moral arbiter under the ethic of care, it must attempt to understand dilemmas of inequality from the perspective of the party seeking redress.

In order for the Court to one day step into the shoes of a homosexual couple pursuing the fundamental right to marry, the Justices must develop a "humane imagination," the facility to recognize humanity in people who are different. ${ }^{49}$ Granted, it takes courage to approach the subject of homosexuality "with open minds rather than fixed certainties, with hearts full of compassion rather than repugnance."so But we do not expect less from the judiciary than principled fortitude in upholding equal protection of the law and other constitutional guarantees. Stretching the moral imagination is a question of willpower; ${ }^{.1}$ empathy is the tool to accomplish it. ${ }^{52}$ By bringing the "other's" perspective to the forefront, feminism seeks to confront the assignment of difference by the judicial "self" - and pull the judiciary into the web of humanity. ${ }^{63}$ Empathy

47. Although the Court should hesitate before imposing its own value choices, the goal of objectivity should not paralyze the Court, preventing it from considering collective goals such as equality and values held by those seeking access to protected rights. Impartiality, after all, is only a mask: "The idea of impartiality implies human access to a view beyond human experience, a 'God's eye' point of view. Not only do humans lack this inhuman perspective, but humans who claim it are untruthful ...." Minow, Justice Engendered, supra note 6, at 75 .

48. See Kronman, Paternalism and the Law of Contracts, 92 YALE L.J. 763, 792-94 (1983) (likens task of moral decisionmaker to anthropologist who enters imaginatively into tribe's own world and sees it from within).

49. See C. BlaCK, JR., The Humane Imagination in the Great Society, in The Humane ImagiNATION 4 (1986) (the "humane imagination" is "the imagination of the feeling and believing and knowing inwardnesses of others" which must be continually tuned and retuned "by checking it against clues in language and behavior"); Gilligan \& Wiggins, supra note 37, at 14. ("[A] more fluid conception of the self in relation to others is tied to the growth of affective imagination, the ability to enter into and understand through experiencing the feelings of others.").

50. W.S. Coffin, The Courage to Love 40 (1982).

51. Discussing the failure of sex equality, Professor Black has written that "the main ingredient in the pathology of imagination has been lack of male will to try rightly to imagine women, with an extremely large component of a corrupt desire to believe such fantasies about women as would justify the abuses." C. BLACK, supra note 49, at 6 .

52. Empathy captures three phenomena: feeling the emotion of another; understanding, both affectively and cognitively, the experience of another, often by imagining oneself to be in the position of the other; and action brought about by experiencing the distress of another. Henderson, supra note 29 , at 1579 .

53. The adjudicator may be less certain about difference when there is occassion for connection. Fiction is one source of empathic connection for it has the power to activate the "humane imagination" by calling upon the reader to imagine the inwardness, feelings and distress of a person not known to exist. C. BLACK, supra note 49 , at $8-9$. Perhaps if Justice White had read David Leavitt's Family Dancing he would have been moved to agree with Justice Blackmun in Hardwick that privacy protection is necessary to homosexuals' personal freedom because homosexuality inheres in the "very fiber" of personhood. In "Territory," Leavitt sensitively portrays a young gay man's under- 
promises to force an adjudicator to recognize that his own point of view is not the only truth, but merely one among a continuum. ${ }^{54}$ The awareness of multiple truths relativizes equality in the direction of equity, fusing justice with care. ${ }^{s b}$ Although the imagination has the negative power to block connection through the creation of stereotypes, ${ }^{\text {s6 }}$ the "humane imagination" promises to be a positive source of change and understanding. ${ }^{57}$

In the care framework, the correct moral response depends on the context. ${ }^{58}$ Fairness can only be determined with reference to social reality and the human predicament. ${ }^{80} \mathrm{~A}$ full examination of the context of the homosexual marriage challenge may illustrate not only why justice demands equal protection of fundamental rights, but also how human needs when fully felt may summon response from the courts. The following narrative is intended to develop the context, engage the empathic imagination and reveal the invisible. ${ }^{.0}$

\section{A Portrait Of A Family}

After eight years of living together and caring for one another, Abby and Karen have formed a deep emotional attachment. ${ }^{\text {61 }}$ Three years ago they exchanged private vows of lifetime commitment and rings, as symbols

standing and confession of his sexuality:

Neil finally stood in the kitchen, his back turned to his parents, and said, with unexpected

ease, "I'm a homosexual." The words seemed insufficient, reductive. For years he had believed

his sexuality to be detachable from the essential him, but now he realized that it was part of

him. He had the sudden, despairing sensation that though the words had been easy to say, the

fact of their having been aired was incurably damning.

D. Leavitr, Family Dancing 7 (1984).

54. See Henderson, supra note 29 , at 1653.

55. See C. Gilligan, supra note 9, at 166.

56. The power of stereotypes to block connection must not be underestimated. Even the parents of homosexual children yield to stereotypes' strength, until, for some, the vigor of love counteracts their influence. "Stereotypes shun logic and reason and at least temporarily can block the natural flow of parental affections. But the primal instinct to love and protect one's young, however latent, embodies an immense potential for social reform." Bernstein, My Daughter is a Lesbian, N.Y. Times, Feb. 24, 1988 at $\mathrm{A27}$, col.1.

57. See Minow, Difference, supra note 13, at 173 (Critical social theories attempt to show "how what seems natural in the world is so often the construction of human imagination and that human imagination could itself bring about change.").

58. See C. Gilligan, supra note 9, at 38 .

59. See Scales, supra note 6 , at 1380 .

60. This narrative is a fictional composite portrait of a number of homosexual couples I spoke with during the formative stages of the Note. It is only one example of the homosexual family and is not intended to obscure the differences within the lesbian and gay community, including varying reactions to the entire notion of homosexual marriage. The personal narrative style is intended to interrupt and confront the objectivity of theory. My hope is that by painting a picture rather than solely reporting stark empirical facts, my audience may begin to connect imaginatively with hypothetical claimants to the right to marry-to discern their faces-although the reader can never truly feel the need for equal protection as experienced by those who lack it.

61. Contrary to the myth of promiscuity, a high percentage of lesbians and gay men live with life partners in de facto marriages, in many cases for decades. Single-gender couples share the same principal concerns as heterosexual couples, including equity, loyalty, stability, intimacy and love. See Brief of American Psychological Association and American Public Health Association at 13-15, Bowers v. Hardwick, 478 U.S. 186 (1986) (No. 85-140). 
of their bond. In adopting a common last name, the couple sought to transform their identities from separate individuals to a mutually and publicly defined union. Abby and Karen felt that without the commitment to the endurance of their love, their relationship would be too vulnerable in the face of the societal forces pulling them apart. Far too often, they have been subjected to painful, obscene jeers-and worse-while strolling down the street. The knowledge that they will always be there for each other has increased their hopes for sustained happiness and has enhanced their sense of personal worth and self-respect.

Shortly after their private ceremony, the couple inquired into the possibility of adoption or artificial insemination. ${ }^{62}$ Because they felt strongly about the experience of pregnancy, Abby and Karen opted to utilize the new reproductive technology that would enable them to bear children outside of the heterosexual union. A year ago, Abby gave birth to a son, Nicholas. Karen now hopes that with the impending birth of her child, her parents will begin to acceept her relationship with Abby. ${ }^{63}$

Though this family is happy and self-sufficient, in many ways it is handicapped by the lack of state recognition. Absent the official sanction of matrimony, the community need not accept Abby and Karen's relationship as legitimate and hence deserving of respect. In addition, Abby and Karen are denied the significant economic and legal rewards granted to married couples because of the marital relationship's presumed contribution to social stability. ${ }^{64}$ The state's refusal to extend the right of marriage to Abby and Karen has deprived them of access to the judical forum, not only to protect their property interests in the event of dissolution, ${ }^{65}$ but also to protect their dual parent-child relationship. Karen has no enforceable rights or responsibilities to Nicholas, her psychological child. ${ }^{68}$ Should Nicholas suffer an injury at school when Abby is away on busi-

62. As of $1981,1.5$ million lesbian mothers were living with natural children and a high percentage of them are raising their children with a lesbian partner. See Comment, Second Parent Adoption for Lesbian-Parented Families: Legal Recognition of the Other Mother, 19 U.C. DAvis L. REv. 729, 732 n.12, 741 n.62 (1986). Psychological research reveals that gay and lesbian parents provide their children with healthy home environments. These children do not exhibit more emotional problems than do children of heterosexual couples, nor do they experience any more difficulty with gender identity. See Comment, Assessing Children's Best Interests When a Parent is Gay or Lesbian: Toward a Rational Custody Standard, 32 UCLA L. REv. 852, 882 \& n.192 (1985).

63. It is not uncommon that parents cannot bring themselves to accept their homosexual child's relationship. Several homosexuals I spoke with attribute this to a parental sense of failure as childrearers. See also Bernstein, supra note 56. Parents of homosexual children also express to them their disappointment that the children will not carry on their traditions-that is, they will not marry and raise families. The recognition of homosexual marriage does not promise better relations between homosexual couples and their families, but at least it might diminish the friction engendered by the hostile stance of the law.

64. These rewards include income tax, employment, insurance and health care benefits; intestate succession; spousal testimonial privileges; support and visitation rights; and familial authority in medical emergencies. See Ingram, supra note 4, at 36; Rivera, Queer Law: Sexual Orientation Law in the Mid-Eighties, Part II, 11 U. DAYTON L. REv. 275, 383 (1986).

65. See Rivera, supra note 64 , at 325-327.

66. See Sexual Orientation and the Law § 1.04[3] (R. Achtenberg ed. 1987). 
ness, Karen will have no authority to consent to emergency surgery. If Abby and Karen's relationship should fall apart, Abby would have every right to deprive Karen of her relationship with Nicholas. On the other hand, Karen would not be obliged to contribute towards his support. By withholding the legal protection of marriage, the law denies a relationship that exists for Nicholas and ignores his interests in the security of two parents. Though bound by love to the emotional and financial responsibilities of parenthood, Abby and Karen have no legal protection should that love fade. ${ }^{\text {Bz }}$

To overcome their legal disabilities, Abby and Karen explored alternatives to marital benefits: adult adoption, second parent adoption, domestic partnership benefits, palimony contracts and parenting contracts. These alternatives offer incomplete remedies and their legal enforceability is open to question in most jurisdictions. ${ }^{88}$ More importantly, such options cannot provide the psychological benefits of state-blessed marriage: the enhanced respectability of the loving relationship and its acceptance in the wider community. ${ }^{69}$ Abby and Karen too often feel compelled to conceal their family, to protect it from the harsh gaze of those who perceive it as immoral. They worry that Nicholas may suffer the ruthless taunts and teasing of other children because his family is different. ${ }^{70}$ And though the legal protection of marriage might not insulate their son from prejudice, at least he would know that his mothers' relationship is not immoral in the eyes of the law.

Because the legislature in this heterosexist society does not even acknowledge the existence of homosexual couples, ${ }^{71}$ the courts must respond

67. Courts will inevitably encounter the offspring of these unions, however. In the interest of equity, some have already begun to extend protection. See, e.g., Loftin v. Flournoy, No. 569630-7 (Cal. Super. Ct. Jan. 2, 1985) (psychological parent granted standard visitation rights to child of her lover following "divorce" of lesbian couple); In re Adoption of M. by S. \& A., No. d8503-61930 (Or. Ct. App. Sept. 4, 1985) (psychological parent of lesbian lover's child allowed to adopt as "second parent"). Legal recognition of these families remains the exception to the rule, however.

68. See Sexual. ORIEnTation AND the LAw, supra note 66, \$§ 1.02-.05,1.04, 2.04, 3.04; Rivera, supra note 64, at 324-398. But see In re N.L.D. and D.J.H., No. 17945 (Cal. Super. Ct. Feb. 24,1986 ) (first joint adoption granted to lesbian couple).

69. See Black, The Supreme Court, 1966 Term-Foreword: "State Action," Equal Protection and California's Proposition 14,81 HARv. L. REv. 69, 101 (1967) ("To be treated as a full member of the society is to be accepted as an equal in the public life of the community."); Glendon, Marriage and the State: The Withering Away of Marriage, 62 VA. L. REv. 663, 685 (1976) (marriage, as opposed to cohabitation, provides "attestation to the relevant community").

70. Though the children of single-gender couples may be subject to community intolerance, this is not a valid reason to deny homosexuals the right to parent or the right to marry. "The Constitution cannot control such prejudices but neither can it tolerate them. Private biases may be outside the reach of the law, but the law cannot, directly or indirectly, give them effect." Palmore v. Sidoti, 466 U.S. 429,433 (1984) (custody could not be denied to interracial couple on basis that child would be subject to pressures and stresses of prejudice not present if child were living with parents of same racial origin); see also M.P. v. S.P., 169 N.J. Super. 425, 438, 404 A.2d 1256, 1263 (1979) (threat of community intolerance insufficient to deny custody to lesbian mother).

71. In Watkins v. United States Army, 837 F.2d 1428 (9th Cir. 1988), Judge Norris attributed the improbability of political redress for homosexuals to lack of empathy and gays' invisibility:

[M]any of us, including many elected officials, are likely to have difficulty understanding or 
meaningfully to the deprivation of their basic civil rights such as marriage. Members of the judiciary must open their eyes to segments of humanity shielded from their view and listen to the voices of those, like Abby and Karen, appealing to them for the equal protection of laws essential to the preservation of their relationships. The mechanistic approach of traditional analysis only perpetuates their silence. By immersing itself in the jungle of doctrinal rules, the judiciary can ignore what is hidden and hide what it wants to ignore. In utilizing empathy to expand their reasoning to include emotion and experience as well as rights, judges may find that when they care about justice they are compelled to act-to rethink equality in human terms. ${ }^{72}$

\section{Towards A Richer Vision Of Equality}

The single-gender marriage challenge demonstrates the need for an ideal of equality sensitive to the problem of detachment, considered a sign of injustice under the ethic of care. The feminine vision suggests that the substantive right to equality is an individual's affirmative right to connection to and response from the community. ${ }^{73}$ If responsibilities to others constitute the underpinnings of morality, then the duties of response and protection must have a place in our vision of equality. The equal protection clause confers more than the right to be treated with equal concern and respect; it encompasses the right to be included. ${ }^{74}$ Equal protection

empathizing with homosexuals. Most people have little exposure to gays, both because they rarely encounter gays and because the gays they do encounter feel compelled to conceal their sexual orientation. In fact, the social, economic, and political pressures to conceal one's homosexuality commonly deter many gays from openly advocating pro-homosexual legislation, thus intensifying their inability to make effective use of the political process.

837 F.2d at 1447.

72. Rather than simply add a new prong to an already multi-pronged, incoherent procedure, the feminist impulse is to start de novo, with a fresh canvas and an expansive imagination. This does not mean that the "mediating principles" suggested here cannot be integrated with existing doctrine; on the contrary, approaches such as Marshall's sliding scale that emphasize contextual decisionmaking accord with these principles. See Minow, Difference, supra note 13, at 136.

73. Feminist scholars have made other proposals to redefine equality. See, e.g., C. MAcKINNoN, supra note 7, at 101-27 (proposing an "inequality" approach requiring courts to strike down policies contributing to the maintenance of an underclass or deprived position because of gender status); Scales, Towards a Feminist Jurisprudence, 56 IND. L.J. 375, 436 (1981) (equality means to cease to impose upon women a bifurcated existence and to restore their opportunity to live a continuous life). Professor Minow's "social relations" approach to equality suggests two judicial strategies for analysis similar to those proposed in this Note-taking the perspective of the group defined as different and exploring the social meanings that exclusion carries in a community. Minow, Difference, supra note 13, at 127-30. However, Minow's standard for equality focuses more on relations of power: "Attributions of difference should be sustained only if they do not express or confirm the distribution of power in ways that harm the less powerful and benefit the more powerful." Id. at 128 .

74. The claim that equal protection compels the right to inclusion is not unique to this Note. Other commentators, however, do not derive the right from the feminine approach to solving moral dilemmas of inequality. See, e.g., Fiss, Groups and the Equal Protection Clause, 5 PHIL. \& Pub. AFF. 107, 147-77 (1976) (equality doctrine should prohibit conduct that disadvantages groups from full participation in society); Karst, supra note 26, at 4 (core of equal protection clause is principle of equal citizenship: "the right to be treated as a respected, responsible and participating member"); Minow, Difference, supra note 13, at 189 ("the prerequisite 'sameness' [is] the shared 'right' to be 
thus imposes upon the state a positive duty of intervention to protect individuals' attachment to the community. ${ }^{78}$ As applied to the homosexual marriage challenge, this ideal of equality mandates that if marriage is a primary unit of community and that community strives to treat all individuals with equal care, then homosexuals have an equal right to establish a connection to the community as a whole through the institution of marriage.

Under the ethic of care, human rights ${ }^{78}$ are claims upon societal institutions that must be honored in order for each individual to meet the responsibilities of his or her fundamental relationships. ${ }^{77}$ The more a certain inequality threatens to damage a key relationship, the greater the necessity of judicial intervention to adjust rules and demand state action. Homosexuals' claim upon the state to the right to marry is necessitated by the need for equal treatment with respect to the state benefits and protection that enable couples to meet their mutual responsibilities to an intimate relationship and promote their inclusion in the community.

To make this ideal of equality meaningful, the Court will have to make connections: connections to the human experience of inequality from the perspective of previously unheard and unseen claimants, ${ }^{78}$ and connections between the right at stake and how it operates in the community to further equality. The Court must also be willing to expand and redefine a

included"); Sherry, supra note 34, at 593 ("anti-discrimination values safeguard the individual's right to belong to the community").

Certainly this was the underlying vision of equality in civil rights cases such as Brown v. Board of Education, 347 U.S. 483 (1954). Perhaps this vision would have been all the more apparent if, rather than categorizing such cases as "desegregation," they were given the more positive appellation of "integration." The goal of the Court in Brown was to strengthen the national community by bringing black and white children together. Through their connection, black and white children would begin to understand and care for one another.

75. The state is not left without any power of exclusion. "[I]t is not impossible both to empathize with the suffering that often produces the sociopath and to accept the necessity of removing him or her from society." Henderson, supra note 29, at 1584.

76. Though feminists have critiqued rights harshly, rights cannot be abandoned altogether. Not only do they serve a protective function but they also have an important emotive value to the individual, for "to claim a right is to assert one's self-worth, to affirm one's moral value and entitlement." Olsen, Statutory Rape: A Feminist Critique of Rights Analysis, 63 TEx. L. Rev. 387, 391 (1984).

77. See Whitbeck, supra note 16 , at 80,82 . Unlike the rights view, the responsibilities view cannot disregard the special responsibilities born of affectional relationships and the vast human suffering that results from the denial of rights integral to those relationships. "[R]elationships between people are what matter, and attributions of difference that build obstacles to such relationships are suspect." Minow, Difference, supra note 13, at 136.

78. That is, the connection to Abby and Karen. Briefs and arguments in future constitutional challenges will have to consciously place the empathic narrative within the legal framework. See Henderson, supra note 29, at 1592. Professor Henderson suggests that empathy may be one of the keys to successful Supreme Court litigation. The amicus brief of National Abortion Rights Action League, excerpting letters from women who had had abortions, may have contributed to the recent reaffirmation of Roe v. Wade in Thornburgh v. American College of Obstetricians, 476 U.S. 747 (1986). See Henderson, supra, at 1635-38. Professor Minow notes that Justice Harlan may have been moved to dissent in Plessy v. Ferguson, 163 U.S. 537 (1896), by Plessy's brief urging the Justices to imagine themselves "with a black skin and curly hair . . . traveling through that portion of the country where the 'Jim Crow Car' abounds. . . ." Minow, Justice Engendered, supra note 6, at 59. 
particular right in accordance with its essential values and function ${ }^{78}$ when that right is too narrowly conceived to include all those who need its protection. Empathy and the ethic of care will not determine the outcome of constitutional challenges to exclusion, but rather inform the balancing undertaken. Utilizing empathy and the feminine moral vision to decide questions of equality promises to yield better results in human terms. ${ }^{80}$

\section{A. The Operation of the Right}

Rather than focus on what state interests justify the selective application of a right, under the feminine approach the Court would initially examine the operation of the right in question and the effects of its denial on those seeking access to it. The more the denial of a right furthers discrimination and prevents attachment to the community, the greater the governmental interest must be to justify that denial. ${ }^{81}$ Homosexuals' inability to marry directly contributes to the discrimination they encounter in all realms of life because of the widespread belief that they are promiscuous sexual deviants. Because their relationship is the root of their exclusion, state-sanctioned marriage is a core means of inclusion for homosexuals that the state may not deny without serious justification.

Though conceived and protected by the Court as a privacy right ${ }^{82}$ marriage operates essentially as a relational right: it enables individuals to relate intimately to one another, and to the wider community ${ }^{83}$ The public function of marriage is particularly important to homosexual couples seeking social acceptance of their relationships. ${ }^{84}$ Public expression of commitment through marriage triggers recognition by and consequent protection from the state, thus promoting a sense of belonging to the community through mutual public identification.

The public function and private values of marriage are in harmony with one another. The state fosters the institution of marriage because society benefits from the transmission of shared values of commitment,

79. See, e.g., L. Tribe, American Constrtutional Law 946 (1978) (in asking whether an alleged right forms part of a traditonal liberty, it is crucial "to define the liberty at a high enough level of generality to permit unconventional variants to claim protection along with mainstream versions of protected conduct."). In his dissent in Hardwick, Justice Blackmun appeared to endorse the idea of painting rights with a broad brush, in response to the values that engender them. 478 U.S. at 199 (Blackmun, J., dissenting).

80. "The strong claim for empathic understanding is that the moral decision, the moral result, will be closer to the good than it otherwise would be." Henderson, supra note 29 , at 1638 .

81. See Karst, supra note 26 , at 63 ("IT] he more that a particular inequality tends to stigmatize or dehumanize its victims, or impair their ability to participate fully in the society, the more the principle of equal citizenship demands justification in terms of a governmental interest of compelling importance.").

82. See Griswold v. Connecticut, 381 U.S. 479, 486 (1965).

83. If the Court applied feminist insights to its examination of the fundamental right to marry, it would realize that, absent a focus on care, the right is incoherent. Both in its private and public aspects, marriage is primarily about interconnection. Distilled to its fundamental values in the equal protection context, marriage reveals certain characteristics obscured by the rubric of privacy.

84. See Note, supra note 24 , at 1289-91. 
trust and responsibility into the broader community. ${ }^{85}$ Vows of loyalty lend stability and secure expectations both to the relationship and to society. The community is strengthened not only by the potential happiness and responsibility marriage generates, but also by the diversity of couples who exchange marriage vows. ${ }^{86}$ By making connections between marriage and its function, the Court may find that the community only stands to benefit from the increased social stability promised by the structured participation of homosexuals in society through the institution of marriage. ${ }^{87}$

The denial of homosexuals' right to marry perpetuates their suffocation in "the closet." From the feminine moral perspective, the isolation and alienation of homosexuals enforced by a state-defined majoritarian morality is a harm in itself and deserving of redress. ${ }^{88}$ Such state-created detachment renders homosexuality both deviant and unknown. ${ }^{89}$

Ignorance leads some to mistakenly regard homosexuality as a matter of acquired taste and, therefore, to penalize gays and lesbians for their perceived deliberate "choice" of an immoral lifestyle. ${ }^{90}$ The overwhelming psychiatric evidence demonstrates, however, that homosexuality is not a matter of simple election but rather a deep-seated psycho-social phenomenon established in early childhood years. ${ }^{91}$ Personal knowledge as well as

85. These values further citizenship in in a democratic state. See Hafen, The Constitutional Status of Marriage, Kinship, and Sexual Privacy-Balancing the Individual and Social Interests, 81 Mich. L. REv. 463, 479-484, 559 (1983).

86. See Roberts v. United States Jaycees, 468 U.S. 609, 618-19 (1984) (marriage and family bonds foster diversity).

87. For example, state recognition of homosexual marriage may promote public health interests by encouraging long-term monogomous relationships that reduce the threat of sexually transmitted diseases, such as AIDS. The support obligations and clarification of rights that accompany marriage would benefit the children of homosexual parents and may reduce the community's welfare burdens.

88. The state has isolated homosexuals from the community by depriving them not only of marriage but also of connections to the professional work world, to government service and to the country itself. See, e.g., Acanfora v. Board of Ed., 491 F.2d 498 (4th Cir. 1974) (transfer of openly homosexual teacher upheld); Dronenburg v. Zech, 741 F.2d 1388 (D.C. Cir. 1984) (Navy regulation mandating discharge for homosexual conduct upheld); Velez-Lozano v. INS, 463 F.2d 1305 (D.C. Cir. 1972) (aliens may be deported for having engaged in sodomy within five years of entry into United States).

89. The legal invisibility of single-gender relationships results largely from institutional heterosexism, rather than from homophobia. Herek, The Social Psychology of Homophobia: Toward a Practical Theory, 14 N.Y.U. Rev. L. \& Soc. Change 923, 925 (1986).

90. See Marmor, Overview: The Multiple Roots of Homosexual Behavior, in Homosexual BEhavior: A MODERN ReApPraisal 19 (J. Marmor ed. 1980); Warren, Homosexuality and Stigma, in Homosexual. Behavior, supra, at 125, 138. Such ignorance breeds fierce contempt and irrational fear-the symptoms of homophobia. Though in its most pathological form homophobia stems from a deep-seated insecurity about one's own sexuality and gender identity, the most prevalent source of homophobic reactions is simple ignorance about homosexuality. See, e.g., Marmor, supra. Ultimately, ignorance can provoke violence. The National Gay Task Force reports that in eight cities, one out of five gay males and one out of ten lesbians have been punched, kicked, hit or beaten because they are gay or lesbian. Brief Amicus Curiae for Lesbian Rights Project, et al., Bowers v. Hardwick, 478 U.S. 186 (1986) (No. 85-140) (reprinted in 14 N.Y.U. Rev. L. \& Soc. Change 953, 967 n.37 (1986)).

91. See Green, Patterns of Sexual Identity in Childhood: Relationship to Subsequent Sexual Partner Preference, in Homosexual BeHavion, supra note 90; see also Baker v. Wade, 553 F. Supp. 1121, 1131 n.19 (N.D. Tex. 1982) ("Sexual preference is fixed at an early age (probably before age 6) ...."), appeal dismissed, 743 F.2d 236 (5th Cir. 1984); see generally C.A. TRIPP, The Homosexual Matrix (1975); D.J. West, Homosexuality Re-Examined (1977). Since 
empirical evidence may be necessary to debunk the cruel stereotyping of gays and lesbians as promiscuous sexual deviants. Through personal contact with homosexuals, heterosexuals may be compelled, by the impulses of care and response, to be more tolerant of difference. ${ }^{92}$ To a significant degree, such understanding may take root only through communities' open acceptance of homosexual couples. ${ }^{93}$ By recognizing homosexual relationships in the public arena of marriage, the law may help to dismantle the irrational fears and prejudice homosexuality elicits and enable singlegender couples to lead lives of dignity and self-respect.94

\section{B. Community Resistance and Prioritizing Voices}

Just as the Court cannot ignore homosexual couples' need for attachment to the community under the feminine approach to inequality, the Court also cannot ignore the community's resistance to that attachment, as voiced through the State. The issue of homosexual marriage engenders diverse reactions; one is hostility, rooted in the belief that homosexual relationships are immoral..$^{95}$ The connection between marriage and societal recognition triggers the morality debate. If the immorality argument was persuasive in Hardwick, where homosexuals claimed only the right to engage in private sexual conduct free from state intrusion, it poses an even graver barrier to homosexuals' claim to a legal status conferred by the state as a benefit for conduct the state wants to encourage.

After scrutinizing the legitimacy of the majoritarian morality argument, ${ }^{96}$ the Court must decide if it is sufficiently compelling to justify the

nearly all young children are raised by heterosexual families, the popular myth that homosexuality is "contagious" (a myth that impedes the acceptance of homosexuals in the public realm) is unfounded. See Marmor, supra note 90, at 19-20.

92. Public opinion polls reveal that people who know at least one openly gay man or lesbian are more likely than others to extend positive attitudes towards homosexuals as a group. But only about $30 \%$ of the American public claims to know openly gay people. See Herek, supra note 89 , at 928 .

93. See id. at 928 .

94. I have no empirical proof that the legal sanction of marriage will open doors of understanding for homosexuals in society. Yet my own musings on homosexual marriage began with personal experience, when my mother received a birth announcement from the lesbian daughter of an old friend. Jessica had her baby Alexander by artificial insemination and she is raising him with Donna, her lover of some years. The birth announcement and subsequent communications between my family and Jessica's opened my eyes to an entire segment of our population hidden because of misunderstanding. This family is the object of disgust to those who do not know its members firsthand. I am saddened that we as a society are unwilling to recognize, much less lend support to, this loving family.

- The feminist method validates the personal experience of injustice as true evidence. "Consciousness raising means that dramatic eye-witness testimony is being given; it means, more importantly, that women now have the confidence to declare it as such. We have an alternative to relegating our perception to the realm of our own subjective discomfort." Scales, supra note 6, at 1402 . See Conversation, supra note 32, at 49-50 (Menkel-Meadow).

95. It may be difficult to actually gauge majoritarian sentiment as to the immmorality of homosexuality. Twenty-five states have decriminalized homosexual sodomy in the past fifteen years.

96. The Court must critically examine the immorality issue, for too often morality is the veil for prejudice, fear and religious values, see Veitch, The Essence of Marriage-A Comment on the Homosexual Challenge, 5 ANGLO-AM. L. REv. 46 (1976), all of which cannot legitimize laws that selectively abridge fundamental rights. See Palmore v. Sidoti, 466 U.S. 429 (1984) (prejudice against inter- 
exclusion of homosexual relationships from state protection. ${ }^{97}$ The Court thus must determine which human voices count-those of couples like Abby and Karen claiming access to a fundamental right, or those of community members offended by including such couples through the institution of marriage. ${ }^{88}$ The Fourteenth Amendment makes this seemingly onerous task easier, for, under its command, the judiciary must listen to those competing voices with one ear tuned to the underlying value at stake: equal protection. Empathy and care, therefore, inevitably connect with rights and abstract principles to resolve these dilemmas. ${ }^{99}$ Though the Justices may be tempted to avoid responsibility by turning to the "majority" for an answer when they are troubled by the decision of whether a group may be excluded from constitutional protection, they may not do so without offending the substantive core of the amendment. ${ }^{100}$ Deference to majoritarian morality must be tempered by equal protection principles. The voices of the invisible - of those oppressed by inequality at the hands of the majority-deserve priority.

This Note contends that under the expanded vision of equality, both the principle of equal justice, insulating fundamental rights and equal access to them from majoritarian domination, ${ }^{101}$ and the positive morality of care, requiring the right to inclusion to preserve relationships, trump moral orthodoxy. ${ }^{102}$ From the perspective of the "other," a moral element

racial couple in custody context); City of Cleburne v. Cleburne Living Center, 473 U.S. 432 (1985) (fear of the mentally retarded); Epperson v. Arkansas, 393 U.S. 97 (1968) (religious ban on teaching evolution). The freedom to marry is partially granted to foster diversity and hence to reduce the fear of intimate associations differing from the societal norm, like the interracial couple in Loving v. Virginia, 388 U.S. 1 (1967). Though Virginians in 1967 may have feared the acceptance of interracial marriage, which was not only a legal but a deeply ingrained social taboo, such fear could not impede the fundamental right to marry.

97. There is no escaping such difficult and often unpalatable value choices raised by equal protection challenges; under the feminist method, the Court must openly address them rather than disguise them in tiers of scrutiny.

98. "The more decisionmakers try to listen to every human voice, the more they try to see events from the perspective of every participant, the more they seek a complete understanding of the human condition and perfect justice, the more difficult they will find it to apply legal rules and to assign responsibility." Yudof, supra note 33, at 605.

99. Judge Wald asserts that "[a]lthough human voices can be heard on both sides of any legal dispute, we ultimately are forced back to some abstract principle or value to compare, weigh and choose between these human voices." Wald, Disembodied Voices-An Appellate Judge's Response, 66 TEx. L. REv. 623, 625 (1988). Interestingly, Judge Wald questions whether the advent of more women on appellate courts will mean a greater emphasis on connections and caring-whether the human voice and Carol Gilligan's "different voice" are "tonally related." Id. at 628 . Gilligan herself writes that "[t]o understand how the tension between reponsibilities and rights sustains the dialectic of human development is to see the integrity of two disparate modes of experience that are in the end connected." C. Gilligan, supra note 9 , at 174.

100. The Fourteenth Amendment imposes an independent obligation of equal treatment on majoritarian rule not to draw invidious distinctions among its citizens. The Fourteenth Amendment is not value-neutral; it insists that the state presumptively treat individuals and relationships as members who "belong," and that the Court be especially sensitive to those who upset the majority because of their biological or deep psycho-social differences.

101. See West Va. State Bd. of Educ. v. Barnette, 319 U.S. 624, 638 (1943) (fundamental rights may not be submitted to vote).

102. Loving, 388 U.S. 1 (1967), supports this proposition. The widespread belief that interracial 
introduced by empathy, the "moral majority" is itself immoral: it threatens to annihilate loving relationships. The morality of marriage is that of caring and shared commitment: the mutual promise, induced by love, to act responsibly towards one another. To be fully respected as members of the community, homosexual couples must be treated as capable of taking on that responsibility. ${ }^{103}$

Perhaps there will come a time when we see that what turns any relationship-between man and woman, man and man, or between woman and woman-into a moral one is the existence of love and devotion to one another, ${ }^{104}$ and that the mode of expressing love is fundamentally a private rather than a state concern. We will shield that love from the state's judgment because the relationship at stake takes precedence over the possible offense the thought of certain expressions of love may cause to distant third parties. ${ }^{108}$

\section{Expanding the Definition}

The positive values associated with marriage, and its functional contribution to community stability are not exclusive to the heterosexual relationship; nor does the transmission of values within a relationship, or into the larger community, depend on gender opposition or sex-role stereotypes. Though the traditional definition of marriage as the union of man and woman has been a fixed star in the ever-changing constellation of the family, that definition must change to render the fundamental right to marry truly effective for all individuals regardless of sexual orientation. To redefine marriage according to its essence as the union of two individuals who publicly proclaim a mutual moral commitment to their deep emotional bond, the Court need only expand its imagination to connect to the immediacy of inequity experienced by homosexual couples. ${ }^{108}$

marriage was immoral could not justify an anti-miscegenation statute that was both invidiously discriminatory and overly intrusive on the basic civil right to marry. See Hardwick, 478 U.S. at 221 (Stevens, J., dissenting) ("[T]he fact that the governing majority in a State has traditionally viewed a particular practice as immoral is not a sufficient reason for upholding a law prohibiting the practice; neither history nor tradition could save a law prohibiting miscegenation from constitutional attack.').

103. See Karst, supra note 26 , at 9-10.

104. Discussing the range of reactions to a man and his gay lover, a psychologist noted: "It was children, and mothers with children, who were the most understanding. One little girl, after visiting the two men in their home, asked her mother, 'Do they love one another? Well, that's okay then." "B. MaDdox, supra note 45, at 133.

105. The recognition of homosexual marriage will undoubtedly cause personal distress to some public bystanders. Professor Buchanan opposes homosexual marriage, in part because it is "a highly visible act" that enables a couple "to project their relationship into the daily walks of public life." Buchanan, supra note 4, at 568. But such distress may not suffice to impede the exercise of individual liberty. As with speech on a T-shirt that is vulgar, those who are offended by a homosexual couple holding hands or kissing in public can "avoid further bombardment of their sensibilities simply by averting their eyes." Cohen v. California, 403 U.S. 15, 21 (1971).

106. Perhaps rights expand more easily when the Court can see inequality in context. The media coverage of events like "Bloody Sunday" during the Civil Rights era forced the judiciary and the populace to visually experience the suffering of children bruised and trampled during peaceful 


\section{CoNCLUSION}

As the homosexual challenge to marry illustrates, differences among individuals may inhere, in part, in their relationships. The Court has cast aside the pall of majoritarian orthodoxy when it threatens to condemn a family, a marriage, or a way of life merely because it differs from the social norm. ${ }^{107}$ Thus, when fundamental relationships and rights thereto have been endangered, the Court has preserved those relationships despite their "difference" and adjusted definitions and rules accordingly. ${ }^{108}$ Should the Court address the homosexual marriage challenge in the future, it must listen with greater sensitivity to the existing but unspoken feminine voice of care in the law, responsive to the human need for intimate connections. Employing the tool of empathy with care may enable the Court to understand that the fabric of society will not unravel in response to homosexual marriage; rather, its threads will be more richly textured.

The fundamental right to marry necessarily entails the freedom of choice of a spouse. For homosexuals, that choice will be "different." But much of the richness of relationships derives from that very freedom to choose. An expansive vision of equality demands that society affirm differences in the name of freedom and humanity. As Justice Jackson proclaimed in West Virginia v. Barnette, "[F]reedom to differ is not limited to things that do not matter much. That would be a mere shadow of freedom. The test of its substance is the right to differ as to things that touch the heart of the existing order." ${ }^{108}$ Homosexual marriage shakes the existing moral order to its core. Yet society may have to abide with a touch of moral uncertainty out of respect for our constitutional commitment to equality and our moral commitment to justice and care.

marches. The sight of inequity enables the spectator to feel compassion and make connections.

The Ninth Circuit, however, took the leap of expanding the definition of immutability for equal protection purposes in Watkins, partially because the majority empathized with homosexuals. Judge Norris asked: "Would heterosexuals living in a city that passed an ordinance banning those who engaged in sex with persons of the opposite sex find it easy not only to abstain from heterosexual activity but also to shift the object of their sexual desires to persons of the same sex?" 837 F.2d 1428, 1446 (9th Cir. 1987).

107. See Moore v. City of East Cleveland, 431 U.S 494, 504-05 (1977) (city housing ordinance excluding extended family households from definition of family unconstitutional) ("Ours is by no means a tradition limited to respect for the bonds uniting members of the nuclear family. . . . [T]he accumulated wisdom of civilization . . supports a larger conception of the family."); Wisconsin v. Yoder, 406 U.S. 205, 223-24 (1972) (free exercise clause of First Amendment guarantees Amish parents right to keep children out of school after age 14) ('There can be no assumption that today's majority is 'right' and the Amish and others like them are 'wrong.' A way of life that is odd or even erratic but interferes with no rights or interests of others is not to be condemned because it is different."); Loving v. Virginia, 388 U.S. 1 (1967).

108. Moore required the city of East Cleveland to redefine "family" in its housing ordinances, and Loving struck down 16 state anti-miscegenation laws.

109. 319 U.S. 624,642 (1943). 
